\title{
The Role of the Latvian District Heating System in the Development of Sustainable Energy Supply
}

\author{
Gatis Bazbauers ${ }^{1}$, Ginta Cimdina ${ }^{2}$, Riga Technical University
}

\begin{abstract}
The aim of the study is to determine whether and to what extent it is possible to use excess electricity produced by wind power plants during low demand periods for district heat production by heat pumps. Energy system analysis on an hourly basis is conducted at various capacities of wind power plants. The results show that it is possible to increase the share of renewable energy sources, decrease the use of primary energy sources and $\mathrm{CO}_{2}$ emissions per unit of the produced energy, i.e. heat and electricity, by using the surplus electricity produced by wind power in the heat pumps combined with the heat storage.
\end{abstract}

Keywords - District heating, heat pumps, renewable energy, wind power.

\section{INTRODUCTION}

Although the potential of district heating systems to integrate various renewable energy technologies with an intermittent production character is immense, it is as yet underdeveloped. District heating systems should play a considerable role in creating sustainable energy systems in the future. The heat supplied from district heating systems took circa $12 \%$ of the total energy end-use in Latvia during 2008 [1]. The share of district heat in the end-use was only about $7 \%$ smaller than for electricity. However, only $16 \%$ of the district heat was produced from renewable energy sources (RES). Techno-economic calculations show [2] that the investments per $1 \mathrm{MWh}$ of energy produced from RES in wood-fired boiler houses and cogeneration plants (CHP) are lower than those for other renewable technology alternatives. Therefore, an increase in the share of biomass in district heating systems would economically be one of the most optimal paths in changing the country's energy balance in favour of RES in the near term. However, an increase in the use of biofuel is not the only way to strengthen energy independence by utilizing the opportunities provided by district heating systems.

As the share of electricity produced by wind power plants (WPP) continues to increase, solutions for using that power during hours of low demand will become increasingly important. The surplus electricity can be exported but the export of the electricity may be constrained by technical limitations of the electrical networks, or it can be an economically unattractive option, compared to using it within the domestic energy system, due to low price. Therefore, integration of intermittent renewable energy technologies on a large-scale requires flexible consumers which are able to adapt their consumption to the supply from those sources. District heating to a certain extent is able to serve as a flexible consumer of electricity and to participate in the solution of any mismatch between supply and demand of the electricity produced from RES.

The aim of this work was to determine to what extent a district heating system, in combination with heat pumps and heat storage, can serve as a flexible user of wind power in the Latvian energy system. This study was inspired by the study made for the energy system of Denmark [3] with the purpose to analyze national strategies for large-scale integration of RES technologies. The present study aims to determine whether and to what extent it is possible to increase the share of RES, decrease the use of primary energy sources (PES) and $\mathrm{CO}_{2}$ emissions per unit of produced energy in the Latvian district heating and power sectors by using electricity produced by WPP in heat pumps. The ultimate goal of the study is to increase the role of district heating systems in advancing to more sustainable energy supply systems.

\section{METHODS}

Modeling of energy systems with large capacities of renewable energy technologies with intermittent character has to be done with the sufficiently small time-step of calculation. The sufficiently small time-step of calculations allows considering the demand-supply dynamics of electricity and heat supply systems with required precision and arrive at accurate integral values obtained for one year. The Energy System Analysis Model "EnergyPLAN" [4] which is developed at Aalborg University in Denmark was chosen as the modeling tool. "EnergyPLAN" is used for the analysis of large-scale WPP integration into energy systems in combination with other renewable energy technologies, energy storage and transport systems in Denmark and other countries [5-9]. The tool is well suited and used for the characterization of energy supply scenarios which are $100 \%$ based on RES in several countries [10-14]. The strength of the model is the ability to include a combination of various energy and transport technologies in the analysis, consider energy consumption and supply situation on an hourly basis, perform analysis and optimization under various conditions, and obtain a variety of important technical, economical and environmental characteristics of the studied system.

The studied energy system included only district heating and power supply systems, and energy conversion facilities are characterized in Table 1 for the reference case. 
TABLE 1

THE STUDIED ENERGY SYSTEM WHICH IS COMPRISED OF DISTRICT HEATING AND ELECTRICITY SUPPLY SYSTEM

\begin{tabular}{|l|l|l|}
\hline $\begin{array}{l}\text { Type of energy conversion } \\
\text { unit }\end{array}$ & $\begin{array}{l}\text { Installed heat } \\
\text { capacity, MW }\end{array}$ & $\begin{array}{l}\text { Installed electric } \\
\text { capacity, MW }\end{array}$ \\
\hline Boiler plants & 740 & \\
\hline Peak boilers of CHP plants & 1021 & \\
\hline CHP units-CHP mode & 976 & 1119 \\
\hline CHP units-condensing mode & & 857 \\
\hline Biogas plants & & 30 \\
\hline Hydropower plants (HPP) & & 1573 \\
\hline WPP & & 30 \\
\hline
\end{tabular}

Table 1 approximately reflects the existing energy conversion units in the district heating and power sectors of Latvia, with the addition of a new gas turbine combined cycle CHP plant which is currently under construction. The study is made under the assumption that annual gross electricity consumption is $15 \%$ greater than in 2008 , i.e. $9 \mathrm{TWh}$, and the annual gross district heating demand is nearly $20 \%$ lower than in 2008, i.e. 6 TWh. These assumptions correspond to the possible energy system around the year 2020. It will take some time before large capacities of WPP can be added to the energy system, and it can be expected that, due to energy efficiency measures, the district heat consumption may decrease, in spite of new heated space construction during this time. The opposite is expected regarding electricity consumption and, although energy efficiency will also increase in the power sector, electricity demand will most likely go up along with economic expansion. Industrial development, an increased demand for comfort and entertainment in the household sector with improved living standards are the main reasons for growth of electricity demand.

Electricity and heat demand load profiles, as well as the distribution of hydro and wind production on an hourly basis for the year 2008 are used in the calculation. The analysis is performed with the aim of the technical optimization, which means that electricity import/export is brought to a minimum and the solution with the least fuel consumption is sought. This approach differs from the market-economic optimization allowed by the model where the least-costly solution on the basis of the economic costs of each production unit is obtained. For the scenarios without the heat pump, the technical regulation strategy 1 is chosen in which units produce solely according to heat demand [4]. In the district heating systems where CHP units are installed, these units are given priority in dispatching of the heat supply sources. The heat pumps are dispatched afterwards and only then the heat produced by the peak load boilers is added if necessary. If there are no CHP plants in the system, heat supply is only provided by boilers. Then, the capacity of WPP is added to the reference system with increasing size, and the system is analyzed under the conditions of the increased WPP production. The possibilities to use excess WPP electricity in district heating systems are analyzed in the scenarios with an added heat pump and heat storage systems using technical regulation strategy 2 [4]. This strategy means meeting both heat and electricity demand by minimizing the export of electricity mainly by replacing CHP heat production by heat pumps. Thus, electricity consumption is increased simultaneously with a decrease in the electricity production of CHP plants. The power produced in condensing mode covers the difference between demand and production from renewable energy technologies and $\mathrm{CHP}$ in both types of scenarios. If the condensing capacity is not sufficient to cover that difference, the electricity is imported.

The total installed heat capacity of heat pumps is $975 \mathrm{MW}$, which is $42 \%$ of the maximum heat load of the district heating systems, and this remains constant as the WPP capacity is increased. The chosen coefficient of performance (COP) for the heat pumps is 3 . To maintain this COP value, heat pumps have to produce heat at low temperatures and, therefore, the maximum share of heat pumps at any hour is limited to $50 \%$ of the total heat demand. The capacity of the heat storage is 23 GWh which corresponds to approximately one day heat consumption during the winter period. The role of heat storage is to accumulate the excess heat produced by heat pumps during surplus WPP production periods, as well as allow using extra CHP capacity to replace condensing power production when such opportunities arise.

\section{RESULTS AND DISCUSSION}

As demonstrated (Fig. 1), when the heat pumps are added to the energy supply system, the volumes of the net export are considerably lower compared to the system without the heat pumps.

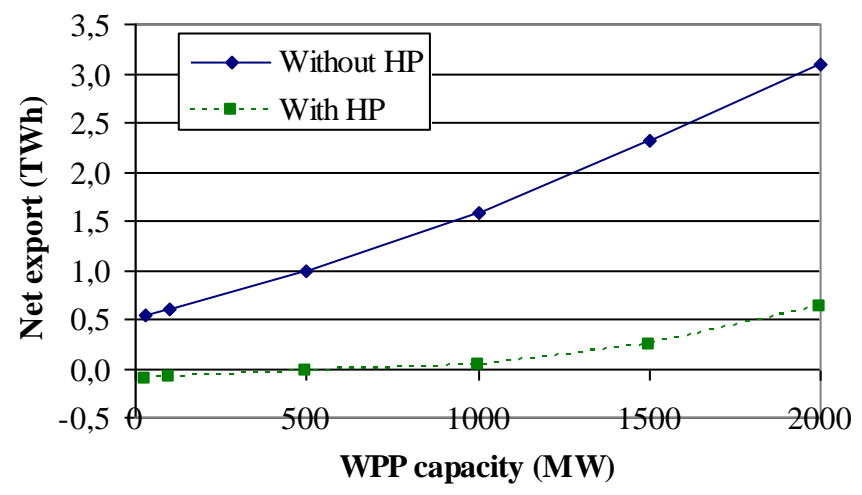

Fig. 1. Heat pumps (HP) allow using most of the surplus electricity produced by WPP when the installed capacity of WPP is below approximately 800 MW. Negative values of net export are imported electricity.

However, a significant portion of the reduction of the net export is due to reduced CHP production in the scenarios with a heat pump as clarified in the description of the technical regulation strategy 2 used in the modeling. This means, that less electricity is produced in the system with heat pumps installed, while the total district heating production is equal in these systems. Therefore, comparison of important 
environmental indicators of the systems with and without the heat pumps needs to be done relative to $1 \mathrm{MWh}$ of produced energy or $1 \mathrm{MWh}$ of the used primary energy.

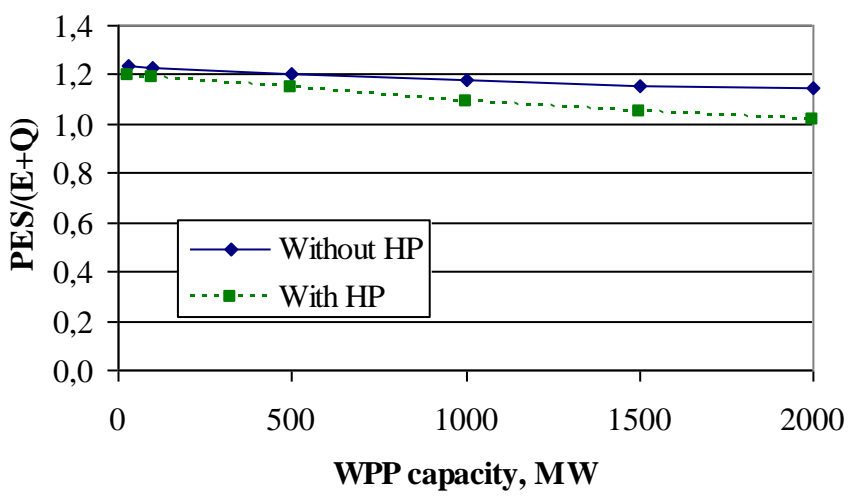

Fig. 2. In the system with heat pumps (HP) total primary energy resource (PES) use for production of electricity (E) and district heat (Q) is lower than for the system without HP.

Thus, when total consumption of primary energy sources is calculated per unit of energy, i.e. electricity and heat combined, the scenarios produced with a heat pump show a reduction of the specific PES consumption (Fig. 2). The difference becomes greater as the installed capacity of WPP increases.

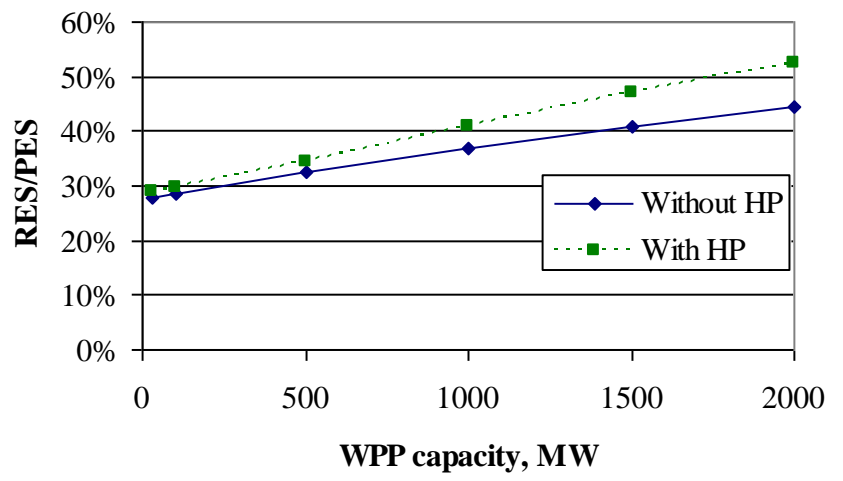

Fig. 3. In the system with heat pumps (HP) share of renewable energy sources (RES) in the total primary energy resource (PES) use is higher than for the system without HP.

The use of heat pumps leads to the increased share of renewable energy sources in the total primary energy use (Fig. 3). Even biomass-fired CHP plants have reduced output in the scenarios with the heat pumps. Another important environmental parameter for the comparison of both scenarios is the emissions of carbon dioxide per unit of produced energy, i.e. electricity plus heat. The installation of heat pumps for utilizing the excess WPP production also helps to improve the energy supply system from the perspective of $\mathrm{CO}_{2}$ emissions (Fig. 4).

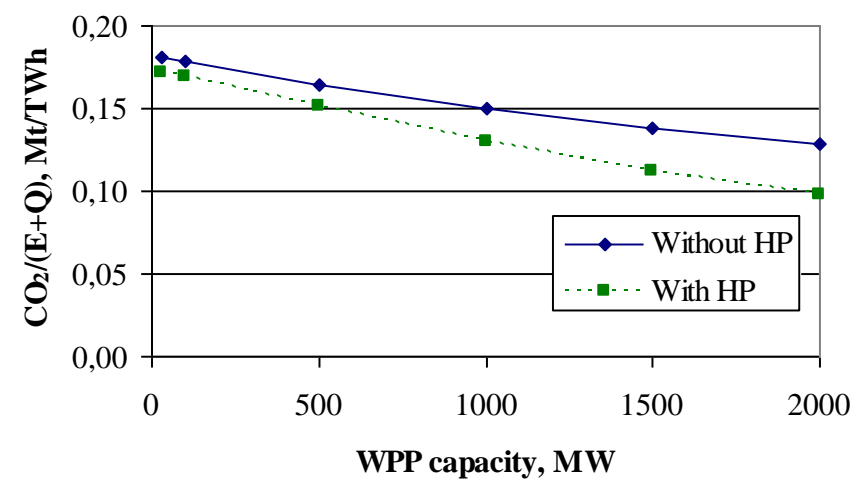

Fig. 4. In the system with heat pumps (HP) carbon dioxide $\left(\mathrm{CO}_{2}\right)$ emissions per unit of produced energy, i.e. electricity (E) plus district heat $(\mathrm{Q})$ are lower than for the system without HP.

The extent of replacement of the fossil-origin electricity produced by CHP and condensing capacities grows as the WPP capacities increase, leading to the increased share of the renewable energy sources and the reduced $\mathrm{CO}_{2}$ emissions (Fig. 3, 4).

It is very unlikely that the total installed capacity of WPP around the year 2020 (electricity and heat demands used for calculations are the expected demands during this time) will exceed $1000 \mathrm{MW}$. Therefore, the sources and mix of primary energy sources for heat and electricity production are analyzed for the system with $1000 \mathrm{MW}$ of WPP installed capacity in more detail.

When heat pumps with the total installed capacity $975 \mathrm{MW}$ and the heat storage with $23 \mathrm{GWh}$ are combined with 1000 MW of WPP, the heat pumps are able to produce approximately $19 \%$ of the total district heat production (Fig. 5). Heat pumps take the share previously supplied by the CHP equipment and boilers.

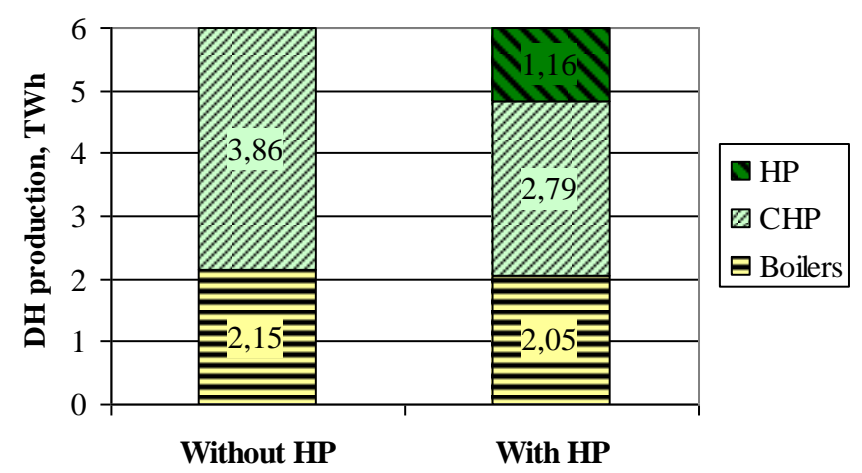

Fig. 5. Heat pumps (HP) produce circa $19 \%$ of the total district heat (DH) when $1000 \mathrm{MW}$ of wind power plant capacity is combined with the heat pumps (975 MW) and heat storage (23 GWh).

The use of heat pumps reduces electricity production and net export (Fig. 6) due to the cut-back of the CHP production and an increased domestic electricity production. Electricity production in the condensing mode is affected very little by HP addition (Fig. 6), since most of the condensing production takes place during the period from June to October when WPP 
production is quite low. Figure 6 also shows that the use of heat pumps increases the share of both renewable energy sources - WPP and hydro power plants (HPP).

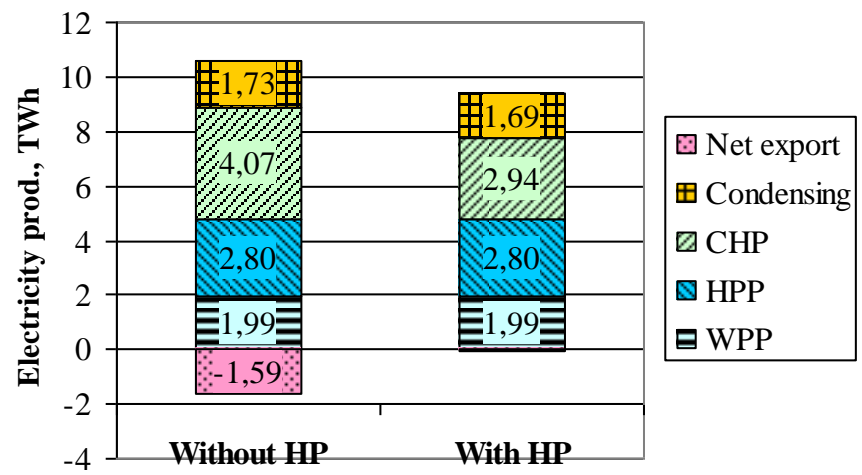

Fig. 6. Total electricity production and net export is reduced when heat pumps (HP) are installed in the system. Electricity produced in the condensing mode falls only slightly but the shares of wind power (WPP) and hydro power (HPP) in the electricity production increases.

Since CHP energy production is partly replaced by WPP, and a large part of CHP production is based on natural gas, the share of renewable energy sources in the total energy (heat and electricity) is larger in the system with heat pumps (Fig. 7). With heat pumps, the share of natural gas in district heat and electricity production decreases from $63 \%$ to $59 \%$, while the share of renewable energy sources (biomass includes wood fuel and biogas) goes up (Fig. 6).

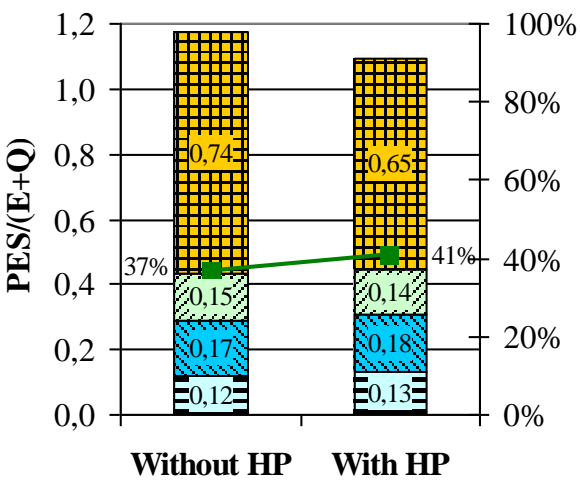

\begin{tabular}{l} 
Natural gas \\
$\because$ Biomass \\
Hydro \\
\hline Wind \\
$\rightarrow-$ Share of RES
\end{tabular}

Fig. 6. Use of heat pumps (HP) allows decreasing share of the natural gas and increasing share of the renewable energy sources (RES) for heat (Q) and electricity (E) production. Due to replacement of CHP and boiler production with wind power, total primary energy consumption (PES) per unit of energy (heat plus electricity) decreases. Biomass includes wood fuel and biogas.

1 TWh of electricity produced by WPP and HPP are accounted as $1 \mathrm{TWh}$ of primary energy used in the calculation. The results reveal (Fig. 6) that primary energy used per one unit of energy (heat combined with electricity) is decreased by $7 \%$ in the studied system with the heat pumps. Thus, the analyzed solution allows not only to reduce the share of the natural gas, but also the total primary energy consumption per unit of produced energy. It has to be noted, that the "quality" of produced energy decreases in the system with heat pumps, i.e. the heat to power ratio of the whole system decreases from 1.8 to 1.6 , since less power is produced based on the same amount of district heat production. However, this deficiency may not be as important as the increase in the share of renewable energy sources.

\section{CONCLUSIONS}

The presented study proves that district heating systems in combination with wind power plants, the heat pumps and the heat storage can increase the share of renewable energy sources in the energy systems. The studied combination improves environmental characteristics, i.e. emissions of carbon dioxide and the use of primary energy sources per unit of energy, which is produced by the energy system with utilization of the excess wind power production. Thus, the considered solution with employment of heat pumps, leads to displacing of natural gas wind power which otherwise may be even lost, if there is no use for the wind power during low consumption hours. The results show that energy companies and energy policy makers should be aware of the opportunities provided by district heating systems to create more sustainable energy systems. Further research on the subject should seek to optimize the share of heat pumps and storage capacity within the energy system by considering environmental and economic benefits when installation of these systems is considered.

\section{REFERENCES}

1. Latvian Energy in Figures. - Riga: Ministry of Economics of the Republic of Latvia, 2009. - 35 p.

2. Bazbauers, G. Current events with regards to use of renewable energy sources in Latvia//Conference "Interests of Latvian energy sector". Riga: Latvenergo, Latvian National Committee of World Energy Council, 2011 [in Latvian].

3. Lund, H. Flexible Energy Systems: Integration of Electricity Production from CHP and Fluctuating Renewable Energy// Int. J. Energy Technology and Policy. - 2003. - 1(3). - 250-261

4. Advanced Energy System Analysis Computer Model EnergyPLAN, Aalborg University, Denmark, version 9.0, February 2, 2011/ Internet. www.energyplan.eu

5. Lund, H. Large-scale Integration of Wind Power into Different Energy Systems// Energy. - 2005. - 30(13). - 2402-2412

6. Lund, H. Large-scale Integration of Optimal Combinations of PV, Wind and Wave Power into the Electricity Supply// Renewable Energy. 2006. - 31(4). - 503-515

7. Lund, H., Kempton, W. Integration of Renewable Energy into the Transportation and Electricity Sectors through V2G// Energy Policy. 2008. - 36(9). - 3578-3587

8. Lund, H., Salgi, G. The Role of Compressed Air Energy Storage (CAES) in Future Sustainable Energy Systems// Energy Conversion and Management. - 2009. - 50(5). - 1172-1179

9. Liu, W., Lund, H., Mathiesen, B.V. Large-scale integration of wind power into the existing Chinese energy system// Energy. - 2011. article in press

10. Lund, H., Mathiesen, B.V. Energy system analysis of $100 \%$ renewable energy systems - the case of Denmark in years 2030 and 2050// Energy. - 2009. - 34(5). - 524-531

11. Krajačić, G. et al. Planning for a $100 \%$ independent energy system based on smart energy storage for integration of renewables and $\mathrm{CO} 2$ emissions reduction// Applied Thermal Engineering. - 2011. - 31. 2073-2083

12. Conolly, D. et al. The first step towards a $100 \%$ renewable energysystem for Ireland// Applied Energy. - 2011. - 88. - 502-507 
13. Porubova, J., Bazbauers, G. Analysis of Long-Term Plan for Energy Supply System for Latvia that is $100 \%$ Based on the Use of Local Energy Resources // Scientific Journal of RTU. 13. series., Environmental and climate technologies. - 2010. - 4. vol. - 82-90

14. Mathiesen, B.V., Lund, H., Karlsson, K. 100\% Renewable energy systems, climate mitigation and economic growth// Applied Energy. 2011. -88 . $-488-501$

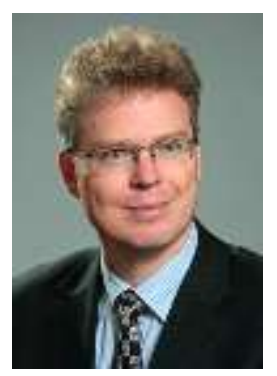

Gatis Bazbauers, Dr.sc.ing., has a diploma of thermal engineering (1990), master of science degree in mechanical engineering (1995), doctor of science degree in engineering (1999) and bachelor's degree in business administration (2002).

He works in the Institute of Energy Systems and Environment, Faculty of Energy and Electrical Engineering at Riga Technical University from the year 2000, and currently is a Professor. He worked as a Managing Director in the energy company "Vattenfall Latvia" (1995-2007), as a Project Manager in the energy consulting company "EEE" (1992-1993) and as an Assistant in the Riga Technical University (1990-1993). The main research interests are district heating systems and cogeneration, energy system planning and economics, renewable energy sources, ecodesign, life cycle assessment. Gatis Bazbauers is a member of the council of Latvia's District Heating Association.

Phone: +371 67089911

E-mail: gatis.bazbauers@rtu.lv

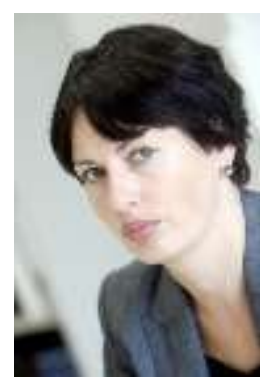

Ginta Cimdiņa, Mr.sc. Env., Riga Technical University, Environment Protection and Heating Systems Institute (2011); Currently Phd. student at Riga Technical University, Environment Protection and Heating Systems Institute.

Ginta Cimdina is working in energy sector for 17 years and she has extensive experience and knowledge in heating systems planning and restructuring, regulation issues, as well as in use of various fuels in energy production.

Currently Ginta Cimdina works as Finnish energy company Fortum representative in Latvia and "Fortum Latvia" Ltd. Chairman of the Board.

Address: Pasta Street 47, LV-3001, Jelgava, Latvia; Phone: +371 26567908

E-mail: ginta.cimdina@fortum.com

\section{Gatis Bažbauers, Ginta Cimdiṇa. Latvijas centralizētās siltumapgādes sistēmu loma ilgtspējīgas energoapgādes attīstībā}

Centralizētās siltumapgādes sistēmām nākotnē būs pieaugoša nozīme atjaunojamo energoresursu īpatsvara palielināšanā valsts energobilancē. Nozīmīgi pieaugot vēja elektrostaciju saražotās elektroenerǵijas īpatsvaram elektroapgādes sistēmā, aktuāls kḹus jautājums par pārpalikuma elektroenerǵijas izmantošanu zema patēriņa stundās. Tādēḷ nepastāvīgas jaudas atjaunojamo energoresursu elektrību ražojošu avotu plašāka izmantošana un integrēšana energoapgādes sistēmās prasīs patērētājus, kuri elastīgi spēj mainīt patērinuu atbilstoši avotu piegādes iespējām. Centralizētās siltumapgādes sistēmas zināmā apmērā spēj būt elastīgs elektroenerǵijas patēētājs un veikt nepastāvīgas jaudas atjaunojamo energoresursu tehnoloǵiju ražotās elektroenerǵijas izmantošanu. Darba mērḳis ir izpētît, kādā apmērā centralizētās siltumapgādes sistēmas spēj izmantot vēja elektrostaciju ražoto elektroenerǵijas pārpalikumu zema patêriņa stundās, lietojot siltuma sūkṇu un siltuma akumulatoru iekārtas. Izpētes uzdevums ir noteikt, vai un cik lielā mērā ir iespējams palielināt atjaunojamo energoresursu īpatsvaru un samazināt oglekḷa dioksīda emisijas elektroenerǵijas un centralizētās siltumenerǵijas ražošanas procesā, izmantojot vēja ražoto elektroenerǵiju siltuma sūkṇu iekārtās. Centralizētās siltumapgādes un elektroapgādes sistēma ir pētīta, lietojot energosistēmu analīzes modelis "EnergyPLAN", kurš ḷauj analīzi veikt stundu griezumā, un analizēt dažādu tehnolog̣iju kombinācijas. Darba rezultāti parāda, ka vēja elektrostaciju ražotās pārpalikuma elektroenerğijas lietošana siltuma ražošanai siltuma sūkṇu iekārtās, kas apvienotas ar siltuma akumulatoriem centralizētās siltumapgādes sistēmās, l̦auj samazināt primāro energoresursu patēriṇu un $\mathrm{CO}_{2}$ emisijas, un palielināt atjaunojamo energoresursu īpatsvaru, rēķinot uz vienu saražotās enerǵijas (siltuma un elektrības) vienību.

Гатис Бажбауер, Гинта Цимдиня. Роль латвийской системы централизованного теплоснабжения в развитии устойчивой энергосистемы

Системы централизованного теплоснабжения в будущем будут иметь все большее значение в увеличений доли возобновляемых энергоресурсов в народном энергетическом балансе. При значительном увеличением доли электроэнергии, произведённой ветровыми электростанциями в энергосистеме, станет актуальным вопрос об использовании избыточной электроэнергии в часы низкого потребления. Таким образом, расширенное использование и интегрирование в энергетические системы возобновляемых источников энергии с изменчивым характером производства потребует потребителей, которые могут гибко изменять потребление в соответствии с возможностями поставки энергий от этих источников. Системы централизованного теплоснабжения до некоторой степени в состоянии быть гибким потребителем и использовать электричество, произведённое технологиями возобновляемых энергоресурсов. Цель работы состоит в исследовании, в какой степени системы централизованного теплоснабжения могут использовать избыток электроэнергии, произведённый ветровыми электростанциями в часы низкого потребления, используя тепловые насосы и теплоаккумулирующие установки. Исследование заключается в определении того, до какой степени это позволило бы увеличить долю возобновляемых энергоресурсов и сократить выбросы углекислого газа от производственных процессов электро- и теплоэнергий, с помощью использованния электроэнергии, произведённой ветровыми электростанциями в установках тепловых насосов. Системы централизованного теплоснабжения и электроэнергетики исследованы с использованием модели анализа энергосистем "EnergyPLAN", которая позволяет проводить анализ в часовом разрезе и анализировать различные комбинации технологий. Результаты показывают, что использованние избыточной электроэнергии произведённой ветровыми электростанциями в оборудованиях тепловых насосов, в сочетании с тепловыми аккумуляторами в системах централизованного теплоснабжения могут сократить потребление первичных энергоресурсов и выбросов $\mathrm{CO}_{2}$, а также увеличить долю возобновляемых энергоресурсов относительно единицы производимой энергий (тепловой и электрической). 